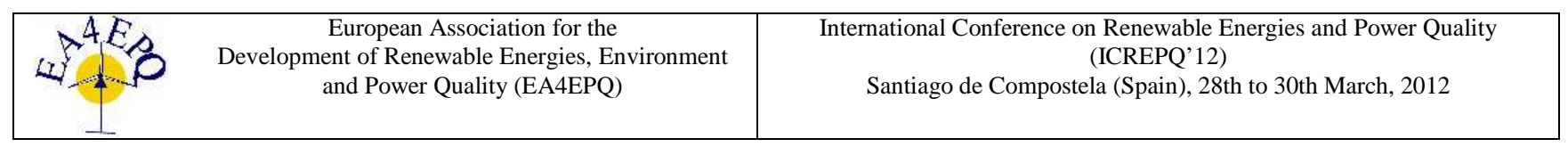

\title{
New Solutions for the Use of Solar Cooling in Hot and Humid Weather Conditions
}

\author{
I. Lafuenti ${ }^{1}$, G. Colangelo ${ }^{1}$, M. Milanese ${ }^{1}$, A. de Risi ${ }^{1}$ \\ ${ }^{1}$ Università del Salento \\ Dipartimento di Ingegneria dell'Innovazione \\ Via per Monteroni - 73100 Lecce (Italy) \\ Phone number:+390832297752, e-mail: ilafuenti@tctsrl.it, gianpiero.colangelo@unisalento.it, \\ marco.milanese@unisalento.it, arturo.derisi@unisalento.it
}

\begin{abstract}
.
Air conditioning is one of the areas that has a high electrical energy consumption, mainly during summer, in hot and humid climates. The major part of the air conditioning systems are based on the vapor compression cycle, but in the last decades solar cooling technology focused the interest of the scientific community and industrial world. Solar cooling deals with a heat driven cycle for cold production. This technology is well represented by absorption refrigerators and desiccant cooling systems. However, in hot and humid climates the latest cycles are not well developed, therefore the systems based on these cycles cannot face the full cooling load needed by the utilizer. Efforts have to be done in order to change their configuration and improve their efficiency. The aim of this paper is to propose new configurations for solar cooling systems and their adaptation to hot and humid climates.
\end{abstract}

\section{Key words}

Solar cooling, desiccant cooling, absorption chiller.

\section{Introduction.}

In hot and humid climates, the cooling load for air conditioning of buildings could be reduced with several techniques: good thermal insulation, double glazed windows, etc.. However, because of the high temperatures, cooling load cannot be reduced to a comfort level using only passive techniques and efficient air cooling systems are required [1]. Solar energy, available in hot climates, could be used to power an active cooling system based on absorption or desiccant cooling cycles. The possibility of producing air cooling systems based on these technologies and their economic benefits are under investigation by the international scientific community. Hallyday et al. [2] evaluated energy savings of desiccant cooling cycle powered by solar thermal collectors in several parts of United Kingdom. Moreover, comparing solar thermal energy with the traditional heating systems, the authors demonstrated the benefits of the former versus the latter. Desiccant cooling is a new technology that was mainly used in the North of Europe. In the South of Europe, where cooling load in summer is very high, this system has not found diffusion yet and there are few investigations that deal with this technique in these regions [3], [4]. Most of the studies regarding desiccant cooling cycles are focused on the energetic analysis. Several authors considered the exergy analysis as well, demonstrating that this approach is useful to identify both the system's theoretical upper limit performance and the highest exergy losses, that have to be minimized in order to approach the theoretical upper limit [5], [6]. Y.J. Dai et al. [7] studied a hybrid air conditioning system that, compared with a traditional vapor compression cycle, showed a better cooling capacity and a better coefficient of performance.

The objective of this paper is focused on new solutions of desiccant cooling cycle for hot and humid climates. In order to accomplish this task, new system layouts are presented and their performance is studied with the help of analytical models. Summer cooling load data have been taken from a wood building located in Lecce, a town in the South-East of Italy, in August. Starting from these data, thermal power, required for the new configurations, is calculated using mathematical models. These models are taken by the scientific literature and deal with single stage LiBr-water absorption cycle and desiccant cooling cycle. Absorption system models are based on mass and energy balance equations and material properties fittings [8]-[12].

Ge et al. [13] listed some analytical and empirical models. Nia et al. [14] simulated mass and energy transfer between desiccant wheels using a model implemented in Simulink and they developed simple correlations to obtain air outlet conditions from inlet air conditions. Zhang, Dai and Wang [15] developed a onedimensional model for the simulation of mass and energy transfer.

\section{Mathematical model for a single stage LiBr-water absorption cycle.}

Single-stage LiBr-water absorption systems are suitable for a summer air treatment unit, because they work with temperatures in a range $75-120{ }^{\circ} \mathrm{C}$, that fits well with flat plate solar collectors operation temperatures. Maximum coefficient of performance for these systems is approximately of 0.7 [8]. Multistage technology gives higher coefficients of performance, but can be used only when high temperatures heat sources are available. 
A sketch of a single-stage LiBr-water absorption system is reported in Figure 1.

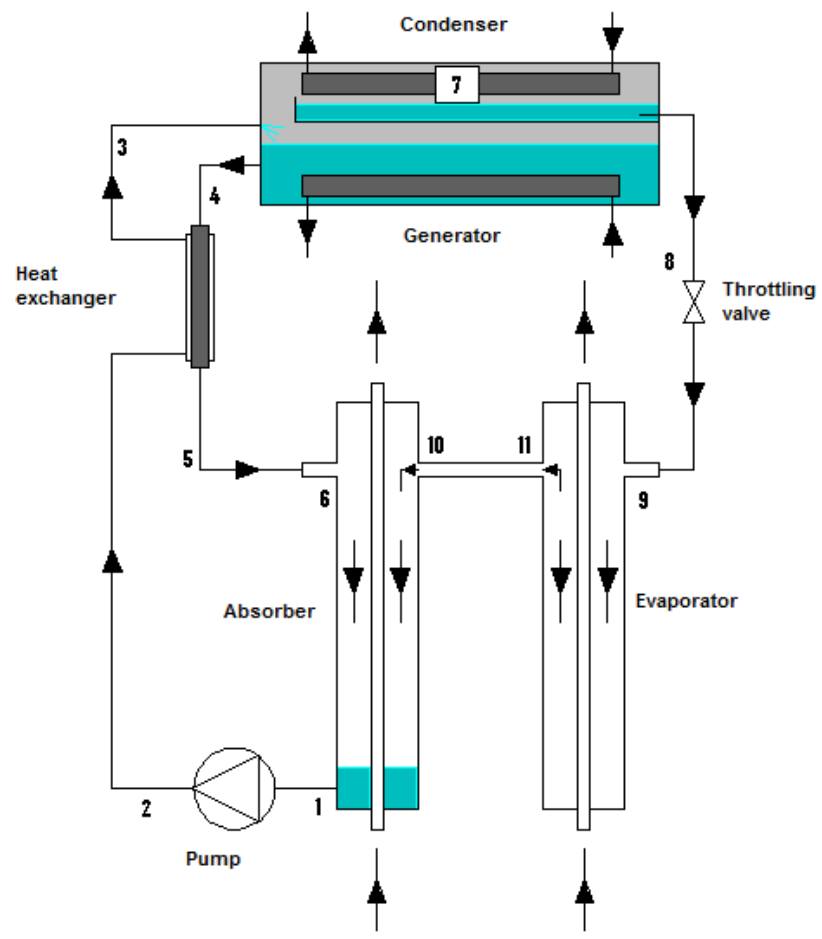

Figure 1 - Single-stage, LiBr-water absorption cycle

In order to make a mathematical model to predict single stage $\mathrm{LiBr}$-water absorption system operation, considering the operation points of Figure 1, the following hypothesis have been made:

1. during steady state operation the fluid is pure water;

2. there aren't pressure changes, except in the throttling valve;

3. at points $1,4,8$ e 11 there is only saturated liquid;

4. at point 10 there is only saturated vapour;

5. pump is isentropic.

LiBr-water solution behaviour has been modelled through empirical equations, present in literature [10]. The design parameters and equations are summarized in Table 1 and in Table 2.

Table 1: Design parameters for single stage LiBr-water absorption chiller of Figure 1

\begin{tabular}{|c|c|c|}
\hline PARAMETER & SYMBOL & VALUE \\
\hline Evaporator temperature & $T_{10}$ & $9{ }^{\circ} \mathrm{C}$ \\
\hline $\begin{array}{c}\text { Outlet temperature of the solution } \\
\text { from the generator }\end{array}$ & $T_{4}$ & $75{ }^{\circ} \mathrm{C}$ \\
\hline Mass fraction of poor solution & $X_{1}$ & $55 \% \mathrm{LiBr}$ \\
\hline Mass fraction of rich solution & $X_{4}$ & $60 \% \mathrm{LiBr}$ \\
\hline $\begin{array}{c}\text { Outlet temperature of the solution } \\
\text { from heat exchanger }\end{array}$ & $T_{3}$ & $55^{\circ} \mathrm{C}$ \\
\hline $\begin{array}{c}\text { Outlet temperature of vapour from } \\
\text { the generator }\end{array}$ & $T_{7}$ & $70{ }^{\circ} \mathrm{C}$ \\
\hline $\begin{array}{c}\text { Mass flow rate of liquid from the } \\
\text { evaporator }\end{array}$ & $\dot{m}_{11}$ & $0.025 \dot{m}_{10}$ \\
\hline
\end{tabular}

Desiccant cooling systems are a type of heat driven open cycle that can be used both to dehumidify and to cool air. These systems are well suited to operate together with solar thermal panels in order to produce an environmentally friendly $\mathrm{HVAC}$ unit.
Table 2: Mass and energy balance equations applied to single stage absorption chiller of Figure 1

\begin{tabular}{|c|c|}
\hline $\begin{array}{c}\text { MASS BALANCE } \\
\text { EQUATIONS }\end{array}$ & $\begin{array}{c}\text { ENERGY BALANCE } \\
\text { EQUATIONS }\end{array}$ \\
\hline$\dot{m}_{9}=\dot{m}_{10}+\dot{m}_{11}$ & $\dot{Q}_{e}=\dot{m}_{10} h_{10}+\dot{m}_{11} h_{11}-\dot{m}_{9} h_{9}$ \\
\hline$\dot{m}_{1}=\dot{m}_{10}+\dot{m}_{11}+\dot{m}_{6}$ & $\dot{Q}_{a}=\dot{m}_{10} h_{10}+\dot{m}_{11} h_{11}+\dot{m}_{6} h_{6}-\dot{m}_{1} h_{1}$ \\
\hline$x_{1} \dot{m}_{1}=x_{6} \dot{m}_{6}$ & \\
\hline$\dot{m}_{4}=\dot{m}_{5}$ & $\dot{m}_{2} h_{2}+\dot{m}_{4} h_{4}=\dot{m}_{3} h_{3}+\dot{m}_{5} h_{5}$ \\
\hline$\dot{m}_{3}=\dot{m}_{2}$ & \\
\hline$\dot{m}_{8}=\dot{m}_{9}$ & $\dot{h}_{8}=h_{9}$ \\
\hline$\dot{m}_{4}+\dot{m}_{7}-\dot{m}_{3}=0$ & $\dot{Q}_{g}=\dot{m}_{4} h_{4}+\dot{m}_{7} h_{7}-\dot{m}_{3} h_{3}$ \\
\hline$\dot{m}_{7}=\dot{m}_{8}$ & $\dot{Q}_{c}=\dot{m}_{7}\left(h_{7}-h_{8}\right)$ \\
\hline$\dot{m}_{1}=\dot{m}_{2}$ & $w=\frac{\dot{m}_{1}\left(p_{2}-p_{1}\right)}{\rho_{1}}$ \\
\hline
\end{tabular}

The physical principle on which the cycle is based is the ability of some materials to absorb humidity on their surface, i.e. silica gel and zeolite. The operating scheme of the system is reported in Figure 2.

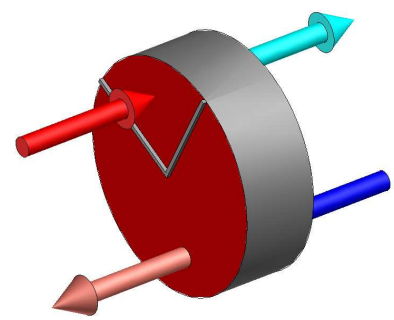

Figure 2 - Operating scheme of desiccant wheel

Desiccant material is charged in a rotating vessel or is distributed on a honeycomb wheel. The vessel (or the honeycomb wheel) turns slowly and is passed through by an air flow, that needs to be dehumidified, and by a hot air flow. The latter air flow is called "reactivation air flow", because it has the task of capturing the humidity that the absorbent material trapped, preventing its saturation. In a desiccant cooling cycle, reactivation air must be heated in order to make the cycle possible. Many of the desiccant materials can be reactivated with relatively low temperatures $\left(50-120^{\circ} \mathrm{C}\right)$. An open cycle air treatment unit with desiccant rotor is represented in Figure 3 . The processes that regard the air treatment are: dehumidification and heating (1-2), cooling in the heat recovery device (2-3) and adiabatic humidification (3-4). Instead regeneration air requires the following processes: adiabatic humidification (5-6), heating in the heat recovery device (6-7), external heating (7-8), humidification and cooling (8-9).

In this paper a new system layout, represented in Figure 3 , is proposed, to make the desiccant cooling cycle capable to cover the heat load limiting the use of electric energy only to ventilation and accessories. 


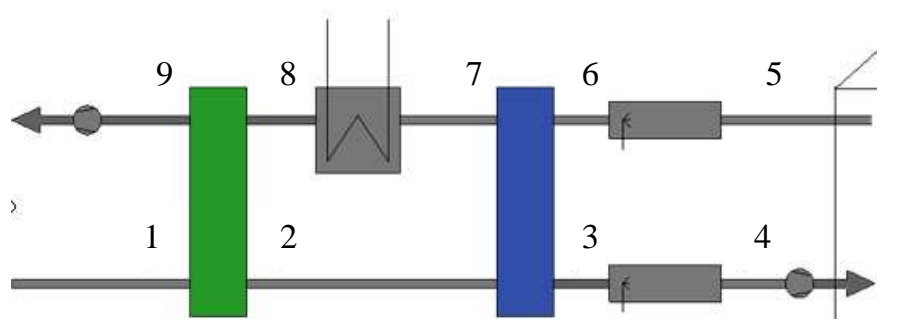

Figure 3 - Open cycle desiccant cooling system

In order to give a performance estimation of the new system configurations, the heat load of a wood building, located in Lecce has been considered. The results from the calculations are summarized in Table 3.

Table 3 - Results of heat load

\begin{tabular}{|l|l|l|}
\hline DESCRIPTION & SYMBOL & VALUE \\
\hline Maximum heat load's hour & $h_{\max }$ & $12: 00$ \\
\hline Total sensible heat load $[\mathrm{kW}]$ & $Q_{S}$ & 16.8 \\
\hline Total latent heat load $[\mathrm{kW}]$ & $Q_{L}$ & 3.2 \\
\hline
\end{tabular}

The proposed solutions are:

A. external air supply, LiBr-Water single stage absorption chiller;

B. internal air partial recirculation, LiBr-Water single stage absorption chiller;

C. LiBr-Water, single stage absorption chiller and desiccant cooling;

D. desiccant cooling with internal air partial recirculation;

E. desiccant cooling with total air recirculation

In this paper Nia's [14] relations have been used to evaluate the efficiency of the new system configurations. The equations are listed below:

$$
T_{\text {out }}=g_{1}(N) g_{2}\left(T_{i}\right) g_{3}\left(d_{t}\right) g_{4}\left(T_{R}\right) g_{5}\left(\omega_{i}\right) g_{6}\left(D_{h}\right) g_{7}(U)
$$

Where:

$g_{1}(N)=-0.0002 N^{2}+0.0112 N+0.4201$

$g_{2}\left(T_{i}\right)=-0.0001 T_{i}^{2}+0.0275 T_{i}+0.7993$

$g_{3}\left(d_{t}\right)=-18.79 d_{t}^{2}+7.92 d_{t}+1.75$

$g_{4}\left(T_{R}\right)=-0.0004 T_{R}^{2}+0.1255 T_{R}+0.6757$

$g_{5}\left(\omega_{i}\right)=594.48 \omega_{i}^{2}+26.76 \omega_{i}+3.79$

$g_{6}\left(D_{h}\right)=-0.039 D_{h}^{3}+0.026 D_{h}^{2}+0.603 D_{h}+0.0912$

$g_{7}(U)=-0.060 U+0.7973$

$\varepsilon=f_{1}(N) f_{2}\left(T_{i}\right) f_{3}\left(d_{t}\right) f_{4}\left(T_{R}\right) f_{5}\left(\omega_{i}\right) f_{6}\left(D_{h}\right) f_{7}(U)$

Where:

$$
\begin{aligned}
& \varepsilon=\frac{\omega_{i}-\omega_{\text {out }}}{\omega_{i}} \\
& f_{1}(N)=-0.0001 N^{2}+0.0042 N+0.4474
\end{aligned}
$$

$$
\begin{aligned}
& f_{2}\left(T_{i}\right)=-0.0001 T_{i}^{2}-0.0031 T_{i}+0.8353 \\
& f_{3}\left(d_{t}\right)=-21.67 d_{t}^{2}+6.93 d_{t}+1.34 \\
& f_{4}\left(T_{R}\right)=-0.0001 T_{R}^{2}+0.0355 T_{R}-0.4924 \\
& f_{5}\left(\omega_{i}\right)=592.77 \omega_{i}^{2}-41.23 \omega_{i}+1.283 \\
& f_{6}\left(D_{h}\right)=-0.0572 D_{h}^{3}+0.0933 D_{h}^{2}+0.6139 D_{h}-0.0922 \\
& f_{7}(U)=-0.0611 U+0.8376
\end{aligned}
$$

\section{Results and discussion.}

A. Unit based on LiBr-Water, single stage absorption chiller, with external air supply.

The first solution (A) handles only external air, while the second one (B) recirculates part of the internal air in order to decrease the energy required to cover the heat loads. The transformations of humid air on these systems are represented in Figure 4.

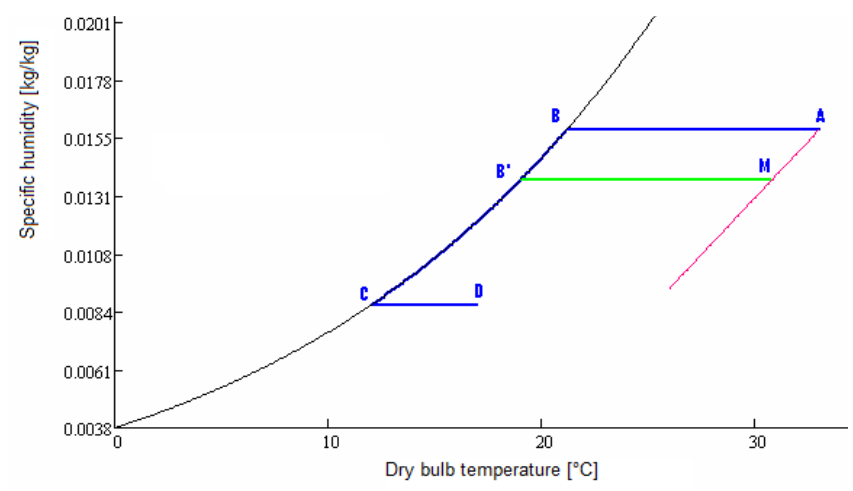

Figure 4 -Humid air cycle made by a LiBr-Water single stage absorption system with external air supply (transformation ABCD) and with a partial internal air recirculation (transformation MB'CD)

Table 4 - Numerical values of the points represented in Figure 4

\begin{tabular}{|c|c|c|c|}
\hline POINT & $\begin{array}{c}\text { ENTHALPY } \\
{[\mathrm{kJ} / \mathrm{kg}]}\end{array}$ & $\begin{array}{c}\text { SPECIFIC } \\
\text { HUMIDITY } \\
{\left[\mathrm{g}_{\mathrm{H} 2 \mathrm{O}} / \mathrm{kg}\right]}\end{array}$ & $\begin{array}{c}\text { DRY BULB } \\
\text { TEMPERATURE } \\
{\left[{ }^{\circ} \mathrm{C}\right]}\end{array}$ \\
\hline $\mathrm{A}$ & 73.5 & 15.8 & 33.0 \\
\hline $\mathrm{M}$ & 66.0 & 13.8 & 30.8 \\
\hline $\mathrm{B}$ & 61.4 & 15.8 & 21.2 \\
\hline $\mathrm{B}$ & 53.9 & 13.8 & 19.0 \\
\hline $\mathrm{C}$ & 34.1 & 8.7 & 12.0 \\
\hline $\mathrm{D}$ & 39.1 & 8.7 & 17.0 \\
\hline
\end{tabular}

Transformation ABCD is associated with the system that takes all the air from the outside, while transformation MB'CD is associated with a partial recirculation of internal air. The results of both cycles are reported in Table 5. Design assumptions about the absorption system showed in Figure 1 are summarized in Table 1. Using cycles data reported in Table 5, balance equations summarized in Table 2 and design parameters reported in Table 1, it is possible to obtain the results in Table 6 . Internal air recirculation allows a recover of a part of the energy required to cool internal air through an adiabatic mixing between internal air and external air. The fraction of recirculated air is the maximum allowed by the technical regulation for internal air quality. 
Table 5 - Results of calculation of cycle represented in Figure 4

\begin{tabular}{|c|c|c|c|}
\hline DESCRIPTION & SYMBOL & $\begin{array}{c}\text { WITHOUT } \\
\text { RECIRC. }\end{array}$ & $\begin{array}{c}\text { WITH } \\
\text { RECIRC. }\end{array}$ \\
\hline Inlet air temperature [ $\left.{ }^{\circ} \mathrm{C}\right]$ & $T_{D}$ & 17 & 17 \\
\hline $\begin{array}{c}\text { Inlet air specific humidity } \\
{\left[\mathrm{g}_{\mathrm{H} 20} / \mathrm{kg}\right]}\end{array}$ & $x_{D}$ & 8.7 & 8.7 \\
\hline $\begin{array}{c}\text { Total air volume flow rate } \\
{\left[\mathrm{m}^{3} / \mathrm{h}\right]}\end{array}$ & $\dot{V}_{a i}$ & 5505 & 5505 \\
\hline $\begin{array}{c}\text { Volume flow rate of } \\
\text { recirculated air }\left[\mathrm{m}^{3} / \mathrm{h}\right]\end{array}$ & $\dot{V}_{\text {air }}$ & 0 & 1761 \\
\hline $\begin{array}{c}\text { External air volume flow } \\
\text { rate }\left[\mathrm{m}^{3} / \mathrm{h}\right]\end{array}$ & $\dot{V}_{\text {aie }}$ & 5505 & 3744 \\
\hline \begin{tabular}{c} 
Evaporator power $[\mathrm{kW}]$ \\
\hline $\begin{array}{c}\text { Power required for air } \\
\text { post heating }[\mathrm{kW}]\end{array}$
\end{tabular}$\dot{Q}_{e}$ & 72.5 & 58.7 \\
\hline
\end{tabular}

Table 6 - Characteristics of LiBr-Water absorption systems

\begin{tabular}{|c|c|c|c|}
\hline DESCRIPTION & SYMNBOL & $\begin{array}{c}\text { WITHOUT } \\
\text { RECIRC. }\end{array}$ & $\begin{array}{c}\text { WITH } \\
\text { RECIRC. }\end{array}$ \\
\hline Evaporator capacity & $\dot{Q}_{e}$ & $72.5 \mathrm{~kW}$ & $58.7 \mathrm{~kW}$ \\
\hline Pump power & $w$ & $0.85 \mathrm{~W}$ & $0.69 \mathrm{~W}$ \\
\hline $\begin{array}{c}\text { Power released by } \\
\text { the absorber }\end{array}$ & $\dot{Q}_{a}$ & $92.9 \mathrm{~kW}$ & $75.2 \mathrm{~kW}$ \\
\hline $\begin{array}{c}\text { Power required by } \\
\text { the generator }\end{array}$ & $\dot{Q}_{g}$ & $97.8 \mathrm{~kW}$ & $79.2 \mathrm{~kW}$ \\
\hline $\begin{array}{c}\text { Power released by } \\
\text { the condenser }\end{array}$ & $\dot{Q}_{c}$ & $77.4 \mathrm{~kW}$ & $62.6 \mathrm{~kW}$ \\
\hline $\begin{array}{c}\text { Coefficient of } \\
\text { performance }\end{array}$ & $C O P$ & 0.74 & 0.74 \\
\hline
\end{tabular}

\section{B. System with absorption chiller and desiccant cooling}

Among the proposed solutions, to adapt the operation of desiccant wheel to hot and humid climates, there is a system that has both desiccant wheel and $\mathrm{LiBr}$-water single stage absorption chiller. In Figure 5, the evaporator of the absorption chiller, integrated in the desiccant cooling cycle, is reported.

The transformations of the air and the numerical values of the points are summarized respectively in Figure 6 and Table 7, while the design parameters are reported in Table 8 . The results of the calculations are reported in Table 9.

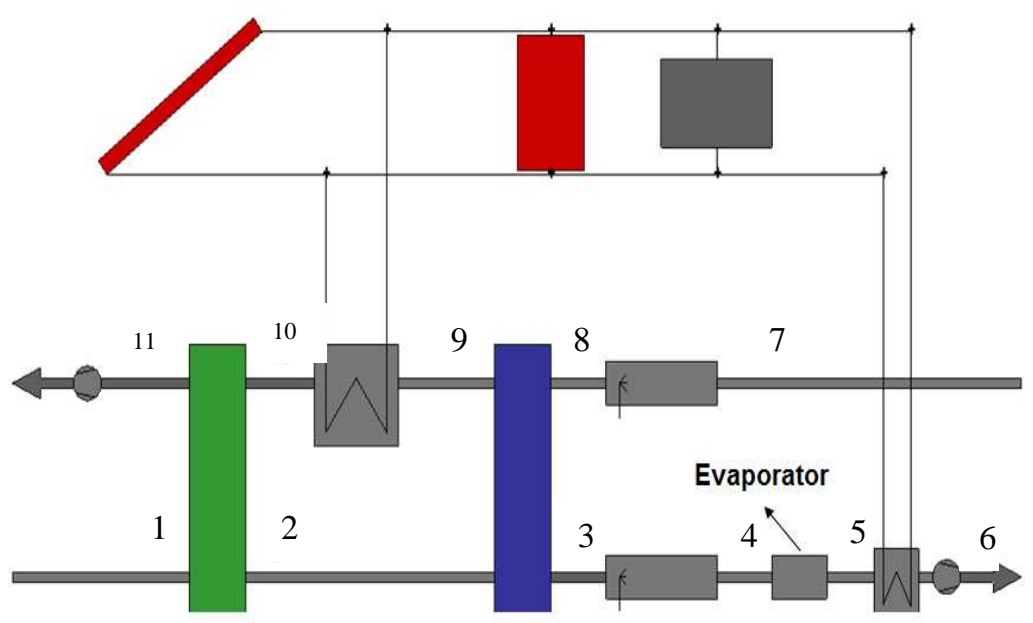

Figure 5 - Sketch of an open cycle desiccant cooling system integrated with an absorption system.

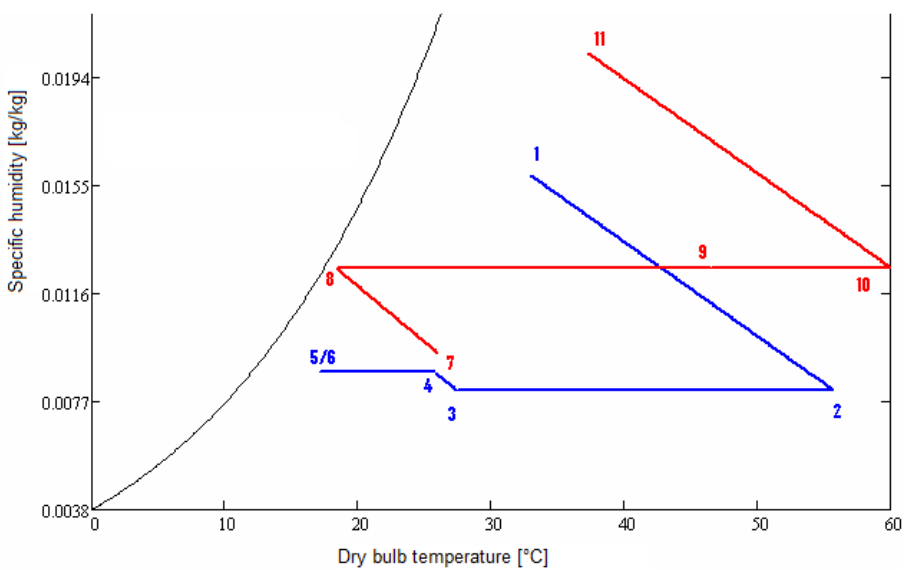

Figure 6 - Humid air cycle with desiccant cooling and LiBr-water absorption chiller of Figure 5

Table 7 - Numerical values of the points reported in Figure 6

\begin{tabular}{|c|c|c|c|}
\hline POINT & $\begin{array}{c}\text { ENTHALPY } \\
{[\mathrm{kJ} / \mathrm{kg}]}\end{array}$ & $\begin{array}{c}\text { SPECIFIC } \\
\text { HUMIDITY } \\
{\left[\mathrm{g}_{\text {H2O }} / \mathrm{kg}\right]}\end{array}$ & $\begin{array}{c}\text { DRY BULB } \\
\text { TEMPERATURE } \\
{\left[{ }^{\circ} \mathrm{C}\right]}\end{array}$ \\
\hline 1 & 73.527 & 15.822 & 33.0 \\
\hline 2 & 76.778 & 8.061 & 55.8 \\
\hline 3 & 48.011 & 8.061 & 27.5 \\
\hline 4 & 48.011 & 8.737 & 25.8 \\
\hline 5 & 39.12 & 8.737 & 17.0 \\
\hline 6 & 39.12 & 8.737 & 17.0 \\
\hline 7 & 50.007 & 9.421 & 26.0 \\
\hline 8 & 50.007 & 12.51 & 18.3 \\
\hline 9 & 78.774 & 12.51 & 46.4 \\
\hline 10 & 92.671 & 12.51 & 60.0 \\
\hline 11 & 89.293 & 20.272 & 37.2 \\
\hline
\end{tabular}

Table 8 - Design parameters of the open cycle desiccant cooling system with absorption chiller

\begin{tabular}{|c|c|c|}
\hline DESCRIPTION & SYMBOL & VALUE \\
\hline External air temperature & $T_{1}$ & $33{ }^{\circ} \mathrm{C}$ \\
\hline External air humidity & $\phi_{e}$ & $50 \%$ \\
\hline Internal temperature & $T_{7}$ & $26{ }^{\circ} \mathrm{C}$ \\
\hline Internal air humidity & $\phi_{7}$ & $45 \%$ \\
\hline $\begin{array}{c}\text { Relative humidity at the } \\
\text { outlet of adiabatic air } \\
\text { humidification }\end{array}$ & $\phi_{8}$ & $95 \%$ \\
\hline $\begin{array}{c}\text { Efficiency of the heat } \\
\text { exchanger }\end{array}$ & $\eta_{s}$ & $75 \%$ \\
\hline $\begin{array}{c}\text { Absorbing material } \\
\text { thickness }\end{array}$ & $d_{t}$ & $0.2 \mathrm{~mm}$ \\
\hline $\begin{array}{c}\text { Desiccant wheel revolutions } \\
\text { per hour }\end{array}$ & $N$ & $15 \mathrm{rph}$ \\
\hline $\begin{array}{c}\text { Hydraulic diameters of rotor } \\
\text { channels }\end{array}$ & $D_{h}$ & 2.33 \\
$\mathrm{~mm}$ \\
\hline $\begin{array}{c}\text { Speed of air flowing through } \\
\text { the rotor channels }\end{array}$ & $U$ & $1 \mathrm{~m} / \mathrm{s}$ \\
\hline $\begin{array}{c}\text { Regeneration air } \\
\text { temperature }\end{array}$ & $T_{l 0}$ & $60{ }^{\circ} \mathrm{C}$ \\
\hline
\end{tabular}

\section{6}


Table 9 - Results of the air handling unit with desiccant wheel and LiBr-water single stage absorption system

\begin{tabular}{|c|c|c|}
\hline DESCRIPTION & SYMBOL & VALUE \\
\hline Air volume flow rate & $\dot{V}_{a i}$ & $5505 \mathrm{~m}^{3} / \mathrm{h}$ \\
\hline Evaporator capacity & $\dot{Q}_{e}$ & $16.3 \mathrm{~kW}$ \\
\hline $\begin{array}{c}\text { Power required for the } \\
\text { regeneration of desiccant } \\
\text { wheel }\end{array}$ & $\dot{Q}_{R}$ & $25.5 \mathrm{~kW}$ \\
\hline $\begin{array}{c}\text { Power required by the } \\
\text { generator of absorption } \\
\text { chiller }\end{array}$ & $\dot{Q}_{g}$ & $22.0 \mathrm{~kW}$ \\
\hline Minimum pump power & $w$ & $0.19 \mathrm{~W}$ \\
\hline $\begin{array}{c}\text { Power released by the } \\
\text { absorber }\end{array}$ & $\dot{Q}_{a}$ & $20.9 \mathrm{~kW}$ \\
\hline $\begin{array}{c}\text { Power released by } \\
\text { condenser }\end{array}$ & $\dot{Q}_{c}$ & $17.4 \mathrm{~kW}$ \\
\hline $\begin{array}{c}\text { Coefficient of } \\
\text { performance of the LiBr- } \\
\text { water single stage } \\
\text { absorption chiller }\end{array}$ & $C O P$ & 0.74 \\
\hline $\begin{array}{c}\text { Total power required by } \\
\text { the system }\end{array}$ & $\dot{Q}_{T O T}=\dot{Q}_{g}+\dot{Q}_{\text {rig }}$ & $47.6 \mathrm{~kW}$ \\
\hline
\end{tabular}

\section{Desiccant cooling with partial air recirculation}

Another solution, proposed to adapt the operation of desiccant cooling to warm and humid climates, is the introduction of a partial recirculation of indoor air, in order to improve the efficiency of the system. System layout is represented in Figure 7 and the design parameters of this system solution are reported in Table 10. The transformations of the air are reported in Figure 8 and the values of the points represented are reported in Table 11. The results of the calculation are reported in Table 12 .

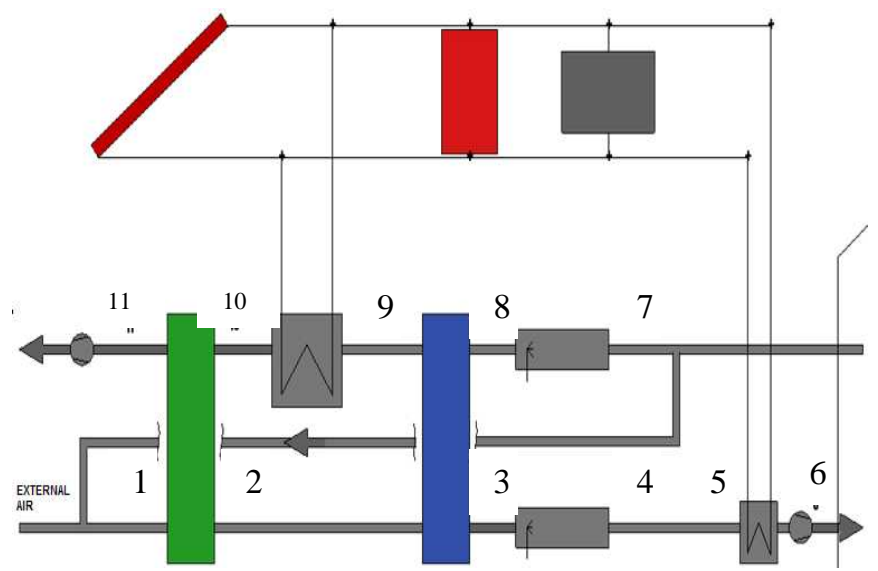

Figure 7 - Sketch of the unit with desiccant cooling and partial internal air recirculation

The last alternative evaluated for the hot and humid climates is the total recirculation of indoor air. The scheme is reported in Figure 9. The transformations of humid air of the total recirculation are represented in Figure 10, while the design parameters are reported in Table 14.
Table 10 - Design data of the open cycle with desiccant wheel and a partial recirculation of indoor air

\begin{tabular}{|c|c|c|}
\hline DESCRIPTION & SYMBOL & VALUE \\
\hline External air temperature & $T_{a e}$ & $33{ }^{\circ} \mathrm{C}$ \\
\hline External air relative humidity & $\phi_{a e}$ & $50 \%$ \\
\hline Internal temperature & $T_{7}$ & $26{ }^{\circ} \mathrm{C}$ \\
\hline $\begin{array}{c}\text { Internal relative humidity } \\
\text { the outlet of adiabatic dehumidification }\end{array}$ & $\phi_{7}$ & $45 \%$ \\
\hline $\begin{array}{c}\text { Heat exchanger efficiency } \\
\text { Absorbing material thickness }\end{array}$ & $\eta_{s}$ & $75 \%$ \\
\hline $\begin{array}{c}\text { Number of revolutions per hour of } \\
\text { desiccant wheel }\end{array}$ & $d_{t}$ & $0.2 \mathrm{~mm}$ \\
\hline Hydraulic diameters of rotor channels & $D_{h}$ & $15 \mathrm{rph}$ \\
\hline $\begin{array}{c}\text { Speed of air flowing through the rotor } \\
\text { channels }\end{array}$ & $U$ & $1.33 \mathrm{~mm}$ \\
\hline Regeneration air temperature & $T_{10}$ & $50{ }^{\circ} \mathrm{C}$ \\
\hline
\end{tabular}

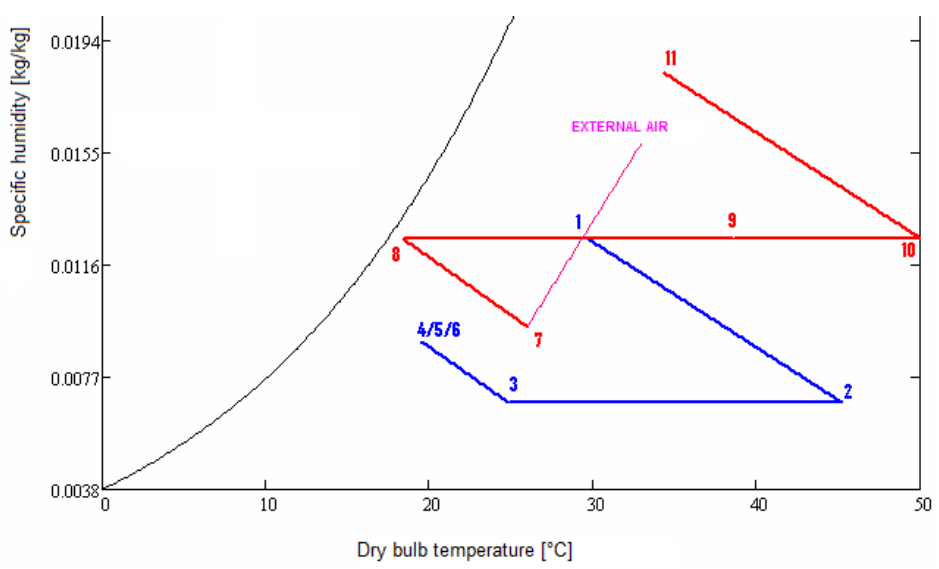

Figure 8 - Humid air transformations of the cycle with desiccant rotor and partial recirculation of indoor air.

Table 11 - Numerical values of the points represented in Figure 8

\begin{tabular}{|c|c|c|c|}
\hline POINT & $\begin{array}{c}\text { ENTHALPY } \\
{[\mathrm{kJ} / \mathrm{kg}]}\end{array}$ & $\begin{array}{c}\text { SPECIFIC } \\
\text { HUMIDITY } \\
{\left[\mathrm{g}_{\mathrm{H} 2 \mathrm{O}} / \mathrm{kg}\right]}\end{array}$ & $\begin{array}{c}\text { DRY BULB } \\
\text { TEMPERATURE } \\
{\left[{ }^{\circ} \mathrm{C}\right]}\end{array}$ \\
\hline 1 & 61.569 & 12.568 & 29.5 \\
\hline 2 & 62.773 & 6.786 & 45.2 \\
\hline 3 & 42.105 & 6.786 & 24.8 \\
\hline 4 & 42.105 & 8.925 & 19.5 \\
\hline 5 & 42.105 & 8.925 & 19.5 \\
\hline 6 & 42.105 & 8.925 & 19.5 \\
\hline 7 & 50.007 & 9.421 & 26.0 \\
\hline 8 & 50.007 & 12.51 & 18.3 \\
\hline 9 & 70.675 & 12.51 & 38.5 \\
\hline 10 & 82.438 & 12.51 & 50.0 \\
\hline 11 & 81.118 & 18.292 & 34.2 \\
\hline
\end{tabular}

Table 12 - Results of the air unit with desiccant wheel and a partial recirculation of indoor air

\begin{tabular}{|c|c|c|}
\hline DESCRIPTION & SYMBOL & VALUE \\
\hline Air volume flow rate & $\dot{V}_{a i}$ & $7616 \mathrm{~m}^{3} / \mathrm{h}$ \\
\hline Recirculated air fraction & $f r$ & 0.51 \\
\hline $\begin{array}{c}\text { Power required to regenerate } \\
\text { the desiccant rotor }\end{array}$ & $\dot{Q}_{r i g}$ & $29.77 \mathrm{~kW}$ \\
\hline
\end{tabular}




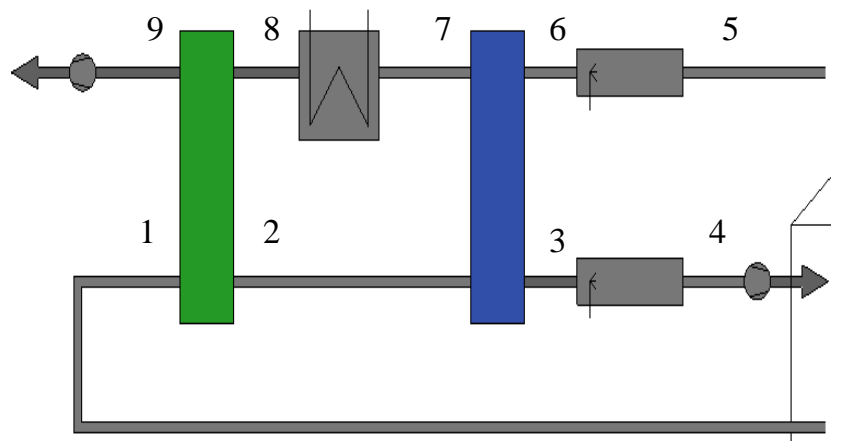

Figure 9 - Desiccant cooling system with total indoor air recirculation.

In order to consider the worsening of heat loads, due to the outdoor air supply, the following equations can be used:

$Q_{S V}=\rho_{a} \dot{V}_{a}\left[h\left(x_{\mathrm{int}}, T_{a e}\right)-h\left(x_{\mathrm{int}}, T_{\mathrm{int}}\right)\right]$

$Q_{L V}=\rho_{a} \dot{V}_{a}\left[h\left(x_{a e}, T_{a e}\right)-h\left(x_{\mathrm{int}}, T_{a e}\right)\right]$

Considering the increasing of the heat loads, due to the external ventilation system, it is possible to obtain the results of Table 15.

The coefficient of performance of an air treatment unit, $C O P_{U T A}$, is the ratio between the heat loads that need to be removed $\left(Q_{S}\right.$ and $\left.Q_{L}\right)$ and thermal power $\left(Q_{T O T}\right)$ that has to be provided to the air treatment unit, in order to ensure its operation:

$$
C O P_{U T A}=\frac{Q_{S}+Q_{L}}{Q_{T O T}}
$$

In Table 16 the performance of the systems based on this parameter are summarized.

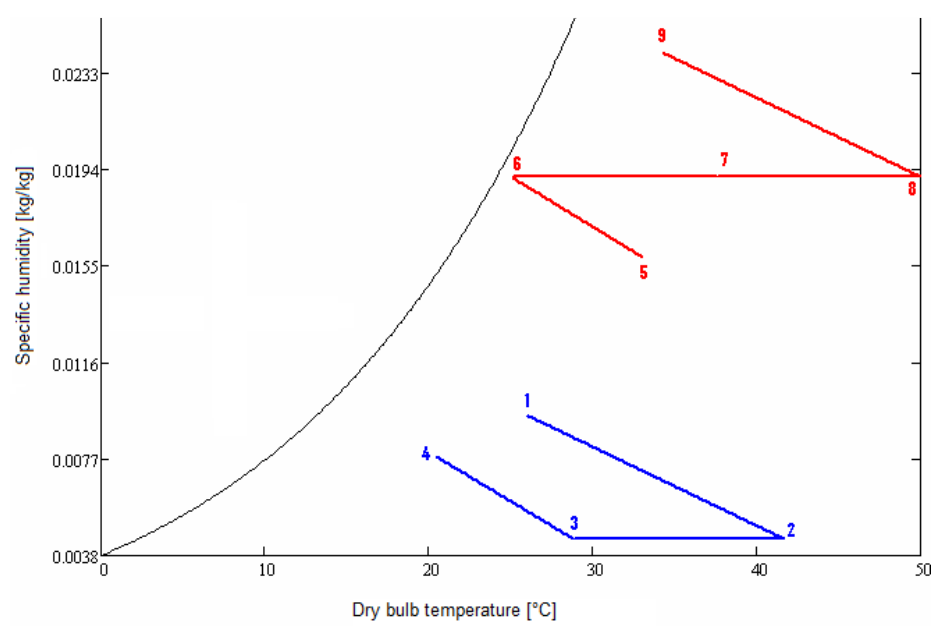

Figure 10 - Humid air transformations of the cycle shown in Figure 9.

The different system layouts have been analysed and compared under different points of view in order to understand pros and cons of each one. The analysis of the behaviour of the absorption system, leads to observe that, in order to face both the sensible and the latent heat loads, from the initial air conditions, a constant specific humidity cooling must be accomplished until the saturation curve is reached. Hereafter, in order to reach the specific humidity for the air entry point, a cooling with dehumidification is required.
Table 13 - Numerical values of the points represented in Figure 10

\begin{tabular}{|c|c|c|c|}
\hline POINT & $\begin{array}{c}\text { ENTHALPY } \\
{[\mathrm{kJ} / \mathrm{kg}]}\end{array}$ & $\begin{array}{c}\text { SPECIFIC } \\
\text { HUMIDITY } \\
{\left[\mathrm{g}_{\mathrm{H} 2 \mathrm{O}} / \mathrm{kg}\right]}\end{array}$ & $\begin{array}{c}\text { DRY BULB } \\
\text { TEMPERATURE } \\
{\left[{ }^{\circ} \mathrm{C}\right]}\end{array}$ \\
\hline 1 & 50.007 & 9.421 & 26.0 \\
\hline 2 & 53.098 & 4.421 & 41.7 \\
\hline 3 & 40.141 & 4.421 & 28.9 \\
\hline 4 & 40.141 & 7.577 & 20.9 \\
\hline 5 & 73.527 & 15.822 & 33.0 \\
\hline 6 & 73.527 & 19.049 & 25.0 \\
\hline 7 & 86.484 & 19.049 & 37.5 \\
\hline 8 & 99.394 & 19.049 & 50.0 \\
\hline 9 & 95.953 & 24.049 & 34.3 \\
\hline
\end{tabular}

Table 14 - Design data of the desiccant wheel with total recirculation of indoor air

\begin{tabular}{|c|c|c|}
\hline DESCRIPTION & SYMBOL & VALUE \\
\hline External air temperature & $T_{5}$ & $33{ }^{\circ} \mathrm{C}$ \\
\hline External air relative humidity & $\phi_{5}$ & $50 \%$ \\
\hline Internal temperature & $T_{l}$ & $26^{\circ} \mathrm{C}$ \\
\hline $\begin{array}{c}\text { Internal air relative humidity } \\
\text { Reactivation air relative humidity at } \\
\text { the outlet of adiabatic } \\
\text { humidification }\end{array}$ & $\phi_{1}$ & $45 \%$ \\
\hline Heat exchanger efficiency & $\phi_{6}$ & $95 \%$ \\
\hline Absorbing material thickness & $d_{t}$ & $0.2 \mathrm{~mm}$ \\
\hline $\begin{array}{c}\text { Number of revolutions per hour of } \\
\text { desiccant wheel }\end{array}$ & $N$ & $15 \mathrm{rph}$ \\
\hline $\begin{array}{c}\text { Hydraulic diameters of rotor } \\
\text { channels }\end{array}$ & $D_{h}$ & $2.33 \mathrm{~mm}$ \\
\hline $\begin{array}{c}\text { Speed of air flowing through the } \\
\text { rotor channels }\end{array}$ & $U$ & $1 \mathrm{~m} / \mathrm{s}$ \\
\hline $\begin{array}{c}\text { Temperature of the air that enters } \\
\text { the regenerator }\end{array}$ & $T_{8}$ & $50{ }^{\circ} \mathrm{C}$ \\
\hline
\end{tabular}

Table 15 - Results of the air treatment unit with desiccant wheel and total recirculation of the indoor air

\begin{tabular}{|c|c|c|}
\hline DESCRIPTION & SYMBOL & VALUE \\
\hline Air volumetric flow rate & $\dot{V}_{a i}$ & $14860 \mathrm{~m}^{3} / \mathrm{h}$ \\
\hline $\begin{array}{c}\text { Required power for } \\
\text { regeneration }\end{array}$ & $\dot{Q}_{r i g}$ & $63.6 \mathrm{~kW}$ \\
\hline
\end{tabular}

Finally, to reach the temperature for the air entry point, a post heating is necessary. Post heating represents an efficiency loss, because it requires an additional energy cost, that is added to that of the generator of the absorption cycle. The hybrid solution, that includes the integration of desiccant cooling with the absorption system, shows a $\mathrm{COP}_{\mathrm{UTA}}$ definitely higher than the absorption cycles alone. Desiccant cooling cycle deals with both the removals of latent heat load, that takes place in the desiccant wheel, and of sensible heat load, that takes place in the heat exchanger, that has a double effect: on one hand it recovers part of the cooling capacity from exhaust air; on the other hand it reduces the thermal power required for the reactivation of the desiccant wheel. The remaining part of sensible heat load is removed by the constant specific humidity, that belongs to the absorption cycle. Even if desiccant cooling system, integrated with the absorption chiller, is more efficient than the absorption chiller alone, it is also more complex and it requires a trickier control system to reach the release conditions of the air. 
Table 16 - Comparison among the performance of the analysed systems

\begin{tabular}{|c|c|c|}
\hline $\begin{array}{l}\text { AIR TREATMENT } \\
\text { UNIT TYPE }\end{array}$ & REQUIRED ENERGY & $\mathrm{COP}_{\mathrm{UTA}}$ \\
\hline $\begin{array}{c}\text { LiBr-Water } \\
\text { Absorption system } \\
\text { with external air } \\
\text { supply }\end{array}$ & $\begin{array}{c}\text { Heat required by } \\
\text { generator and by post- } \\
\text { heating }\end{array}$ & 0.19 \\
\hline $\begin{array}{l}\text { LiBr-Water absorption } \\
\text { chiller with partial } \\
\text { internal air } \\
\text { recirculation }\end{array}$ & $\begin{array}{l}\text { Heat required by the } \\
\text { generator and by post } \\
\text { heating }\end{array}$ & 0.23 \\
\hline $\begin{array}{c}\text { Desiccant cooling } \\
\text { cycle integrated with a } \\
\text { LiBr-water single } \\
\text { stage absorption cycle, } \\
\text { with external air } \\
\text { supply. }\end{array}$ & $\begin{array}{l}\text { Heat required by the } \\
\text { generator and by the } \\
\text { regeneration of the } \\
\text { desiccant wheel }\end{array}$ & 0.42 \\
\hline $\begin{array}{l}\text { Open cycle desiccant } \\
\text { cooling with a partial } \\
\text { internal air } \\
\text { recirculation }\end{array}$ & $\begin{array}{l}\text { Heat required by the } \\
\text { regeneration of the } \\
\text { desiccant wheel }\end{array}$ & 0.67 \\
\hline $\begin{array}{l}\text { Desiccant cooling with } \\
\text { total indoor air } \\
\text { recirculation }\end{array}$ & $\begin{array}{l}\text { Heat required by the } \\
\text { regeneration of the } \\
\text { desiccant wheel }\end{array}$ & $0.31 *$ \\
\hline
\end{tabular}

The solution that uses the internal air recirculation as an integration of the traditional desiccant cooling system requires a less complicated system, because it doesn't require the help of absorption chiller, moreover it has a higher $\mathrm{COP}_{\mathrm{UTA}}$. However total air flow rate is higher than the other solutions, causing higher friction losses. In the last solution there is a heat load worsening due to the external ventilation system, required to ensure air quality, as recommended by the ASHRAE technical regulations. Due to such an increase it might be necessary to integrate the system with a traditional vapor compression chiller. The estimated efficiency of the systems were in the range between 0.17 and 0.76 , depending on the investigated configuration.

\section{Conclusions.}

In this paper, starting from the existing solutions of solar cooling, that is desiccant cooling and absorption chiller, some system innovations have been proposed, with the aim of the adaptation of these technologies to hot and humid climates, facing efficiently the heat loads through the use of solar thermal energy and thus reducing electric energy consumption. Referring to the scientific literature, suitable mathematical models were created, in order to predict the thermodynamic behavior of the systems. The air treatment unit solutions considered were:

1. absorption chiller with or without indoor air recirculation;

2. desiccant cooling integrated with a LiBr-water absorption chiller;

3. desiccant cooling with partial recirculation of indoor air;

4. desiccant cooling with total indoor air recirculation and an external ventilation system.
The most efficient solution in terms of $\mathrm{COP}_{\mathrm{UTA}}$ and in terms of system simplicity is the third one, that is desiccant cooling with partial recirculation of indoor air.

\section{References}

[1] P.M. Congedo, G. Colangelo, G. Starace, "CFD simulations of horizontal ground heat exchangers: A comparison among different configurations", Applied Thermal Engineering, 33-34 (2012), 24-32, Elsevier (UK).

[2] S.P. Halliday, C.B. Beggs, P.A. Sleigh, "The use of solar desiccant cooling in the UK: a feasibility study", Applied Thermal Engineering 22 (2002) 1327-1338, Elsevier (UK).

[3] P. Mavroudaki, C.B. Beggs, P.A. Sleigh, S.P. Halliday, "The potential for solar powered single-stage desiccant cooling in southern Europe", Applied Thermal Engineering 22 (2002), Elsevier (UK).

[4] H-M. Henning, T. Erpenbeck, C. Hindenburg, I.S. Santamaria, "The potential of solar energy use in desiccant cooling system", International Journal of Refrigeration 24 (2001).

[5] M. Kanoglu, M.Ö. Çarpinlıglu, M. Yıldırim, "Energy and exergy analyses of an experimental open-cycle desiccant cooling system", Applied Thermal Engineering 24 (2004) 919-932, Elsevier (UK)..

[6] M.Kanoglu, A.Bolattürk, N.Altuntop "Effect of ambient conditions on the first and second law performance of an open desiccant cooling process", Renewable Energy 32 (2007) 931-946, Elsevier (UK)..

[7] Y.J. Dai, R.Z. Wang, H.F. Zhang, J.D. Yu, "Use of liquid desiccant cooling to improve the performance of vapor compression air conditioning", Applied Thermal Engineering 21 (2001) 1185-1202, Elsevier (UK).

[8] G.A. Florides, S.A. Kalogirou, S.A. Tassou, L.C. Wrobel, "Design and construction of a LiBr-water absorption machine", Energy Conversion and Management 44 (2003) 2483-2508, Elsevier (UK)..

[9] K. Banasiak, J. Koziol, "Mathematical modelling of LiBr$\mathrm{H} 2 \mathrm{O}$ absorption chiller including two-dimensional distributions of temperature and concentration fields for heat and mass exchangers", Internal Journal of Thermal Sciences 48 (2009) 1755-1764, Elsevier (UK)..

[10] J. Sun, L. Fu, S. Zhang, W. Hou, "A mathematical model with experiments of single effect absorption heat pump using $\mathrm{LiBr}-\mathrm{H} 2 \mathrm{O}$ ", Applied Thermal Engineering 30 (2010) 2753-2762, Elsevier (UK).

[11] B. Bakhtiari, L Fradette, R. Legros, J. Paris, “A model for analysis and design of $\mathrm{H} 2 \mathrm{O} \_\mathrm{LiBr}$ absorption heat pumps" Energy Convertion and Management 52 (2011) 1439-1448, Elsevier (UK).

[12] K.A. Joudi, A.H. Lafta "Simulation of a simple absorption refrigeration system" Energy Conversion and Management 42 (2001) 1575-1605, Elsevier (UK).

[13] T.S. Ge, Y. Li, R.Z. Wang, Y.J. Dai, "A review of the mathematical models for predicting rotary desiccant wheel", Renewable and Sustainable Energy Reviews 12 (2008).

[14] F.E. Nia, D. van Paassen, M.H. Saidi, "Modeling and simulation of desiccant wheel for air conditioning", Energy and Buildings 38 (2006) 1230-1239, Elsevier (UK).

[15] X. J. Zhang, Y.J. Dai, R. Z. Whang, “A simulation study of heat and mass transfer in a honeycombed rotary desiccant dehumidifier", Applied Thermal Engineering 23 (2003) 989-1003, Elsevier (UK).

[16] V.Bearzi, "Manuale di Energia solare", Tecniche Nuove, 2009 (Italy).

[17] V.C. Mei, F.C. Chen, Z. Lavan, R.K. Collier Jr., G. Meckler, "An assessment of desiccant cooling and dehumidification technology" Oak Ridge National Laboratory (1992). 